\title{
Polska mowa potoczna w odbiorze Bułgara
}

\author{
Polish colloquial speech according to Bulgarian
}

\author{
Petar Sotirov \\ Wydział Humanistyczny, Uniwersytet Marii Curie-Skłodowskiej, \\ pl. Marii Curie-Skłodowskiej 4 A, 20-031 Lublin, Polska; \\ e-mail: petar.sotirov@poczta.umcs.lublin.pl
}

\begin{abstract}
Abstrakt
Obiektem tekstu jest polska mowa codzienna w opinii nosiciela języka bułgarskiego. Celem jest ujawnienie najbardziej wyrazistych cech polszczyzny mówionej według obserwatora zewnętrznego. Cechy te ujawniają się przy zestawieniu norm używania języka polskiego z bułgarskimi normami mowy. Dla Bułgara polska codzienna komunikacja werbalna jest źródłem licznych zdziwień, ponieważ zauważa on znaczące różnice w porównaniu z używaniem języka w rodzimym społeczeństwie. Różnice te dotyczą rozmaitych aspektów języka polskiego i zachowań językowych Polaków. Ogólnie, według Bułgara mowa polska w sposób wyrazisty prezentuje archaiczny stan słowiańszczyzny, jest ona bardzo uprzejma, dialog jest pełny i przewidywalny, w zakresie wyrażania relacji społecznych przeważa tendencja podtrzymywania dystansu między rozmówcami, a mowę Polaków charakteryzuje socjalizacja obiektu mowy. Bardzo dziwi Bułgara zasada „aktualnej przeszłości” (wyróżniania określonej osoby tytułem, który jest już nieaktualny) oraz zasada „podwyższania stopnia zawodowego" (zwracanie się do obiektu mowy (lub mówienie o nim) w sposób, który wynosi go w hierarchii na pozycję wyższą niż mu jest właściwa). Poczucie znaczących różnic u nosiciela języka bułgarskiego powodują również zjawiska z zakresu językowego obrazu świata, np. asymetrie polsko-bułgarskie w zakresie metaforyzacji językowej.
\end{abstract}

Słowa kluczowe: polszczyzna mówiona; mowa bułgarska; norma mowy; mówiący Polak; obserwator zewnętrzny.

\begin{abstract}
This article revolves around some peculiarities of Polish colloquial speech from the perspective of a speaker of Bulgarian. Its aim is to reveal the most peculiar features of Polish colloquial language as seen by a foreign observer. These features are depicted through a comparison between the norms of colloquialisms in Polish and Bulgarian. To a Bulgarian, Polish colloquial verbal communication can be a source of surprise as the use of language in Polish and Bulgarian tends to differ significantly. These differences refer to various aspects of the Polish language and linguistic behaviour as displayed by Poles. In general, to a Bulgarian Polish language is a distinct representation of an archaic stage of Slavic languages, more polite, with full and predictable dialogues and maintain a distance between the interlocutors in expressing social relations. The language spoken by Poles tends to socialize the object of speech. A Bulgarian native speaker is often astonished by the principle of "the living past" in Polish (referring to somebody with an obsolete title) as well as the principle of "raising the professional status" (referring to or speaking about people in a way raising their position above
\end{abstract}


the actual professional hierarchy). A speaker of Bulgarian spots significant differences in the realm of the linguistic worldview, e.g. Polish-Bulgarian asymmetries in the process of metaphorisation.

Keywords: spoken Polish; spoken Bulgarian; norms of speech; speaking Pole; outside observer.

Zaprezentowane badania mieszczą się w paradygmacie porównawczej analizy dyskursu rozumianego jako „rodzaj oddziaływania społecznego, które realizuje się przy pomocy języka" (Grabias 1997: 264). Ich obiektem jest polska mowa codzienna w opinii obserwatora zewnętrznego w osobie nosiciela języka bułgarskiego zamieszkałego w Polsce. Celem jest ujawnienie jej najbardziej wyrazistych cech, które wynikają ze świadomych bądź nieświadomych zestawień norm używania języka polskiego z bułgarskimi normami mowy. Pojęcie normy mowy ujmowane jest tutaj jako norma kierująca zachowaniami językowymi członków społeczeństwa, dotyczyć może ona różnych parametrów komunikacji werbalnej, zarówno ilościowych, jak i jakościowych (zob. Хъдсън 1995: 156).

Sformułowanie wniosków na temat polskich norm zastosowania języka dokonuje się metodą obserwatora zewnętrznego. Jak wiadomo, metoda ta wykreowana została już dawno temu w ramach badań semiotycznych, w których obserwatorowi zewnętrznemu przyznaje się wyjątkowo ważną rangę. Wynika ona z faktu, że subiekt, który znalazł się w obcym dla niego systemie semiotycznym (w konkretnym przypadku - w nowej wspólnocie ludzkiej), ocenia go odmiennie niż naturalny członek tego systemu. Odmienność polega na tym, że nowy członek zauważa w nim znaki (cechy, właściwości), które dla stałych członków są całkowicie naturalne (Степанов 1979: 103). Z tego powodu, zdaje się, metoda obserwatora zewnętrznego do dziś jest jednym $\mathrm{z}$ istotnych narzędzi w naukach społeczno-humanistycznych ${ }^{1}$.

Analiza porównawcza norm mowy dwóch społeczeństw, świadoma lub nieświadoma, stale towarzyszy życiu przesiedleńca. Dla Bułgara, który uczestniczy w codziennej polskiej rzeczywistości językowej, jest ona źródłem bezliku zdziwień spowodowanych znaczącymi różnicami w porównaniu z normami używania języka w rodzimym społeczeństwie. W niektórych przypadkach różnice powodują bardzo pozytywne uczucia, dlatego zdziwienie przechodzi w podziw, zachwyt, w szczerą akceptację. W innych przypadkach zaś zdziwienie może być nacechowane znakiem negatywnym, ponieważ różnice sprawiają trudności, wręcz dręczą Bułgara, który dąży do pełnowartościowej interakcji werbalnej w polskich realiach.

Pewne aspekty omawianej tutaj problematyki zostały zaprezentowane w kilku poprzednich publikacjach (np. Сотиров 2006; Sotirov 2007). W dalszej części będą one przypomniane, doprecyzowane i poszerzone o nowe spojrzenia na mówiącego Polaka z punktu widzenia (raczej słyszenia) zamieszkałego w Polsce Bułgara.

${ }^{1}$ Potwierdza się to na przykład w badaniach z zakresu lingwistyki kognitywnej, choćby nad stereotypami etnicznymi i narodowymi (zob. Bartmiński 2009). 


\section{Polszczyzna rozbrzmiewająca - ucztą dla Bułgara}

Z powodu istnienia we współczesnym języku polskim szeregu zjawisk archaicznych dla pewnego grona Bułgarów - osób o wykształceniu filologicznym, zajmujących się zawodowo językoznawstwem, dokładniej dialektologią i historią języka - spotkanie ze współczesną polską mową stanowi prawdziwą ucztę, ponieważ dla nich język polski jest niczym maszyna czasu, która przenosi w odległe okresy istnienia języka słowiańskiego. Autentyczną euforię powoduje na przykład fakt istnienia prasłowiańskich nosówek, spółgłoskowej grupy *-dt- (radto, mydto, imadło) i mnóstwa starych słowiańskich leksemów, które w języku bułgarskim już zanikły lub zmieniły swoją semantykę2. Do tego należy dodać fakt, że w języku polskim nie występuje zjawisko redukcji samogłosek w pozycji bez akcentu, dlatego Bułgar ma wrażenie, że przeciętny Polak mówi bardzo starannie i powoli, co również godne jest uznania.

\section{Polska mowa codzienna w świetle teorii aktów mowy}

W opinii Bułgarów polską mowę codzienną cechuje podwyższona frekwencja określonych aktów mowy oraz swoisty sposób językowego wyrażania niektórych $\mathrm{z}$ nich. W konsekwencji odbierana jest ona jako bardzo uprzejma. Jednym z głównych powodów do takiego stwierdzenia jest duża częstość ekspresywnego aktu mowy zawierającego podziękowanie. Wyraz dziękuję lub pochodny od niego rozbrzmiewa tak często, że Bułgarzy ze zdziwieniem dowiadują się o niektórych „swoistych” jego funkcjach. Dla nich na przykład jest dziwne, że wdzięczność wyraża nie tylko odbiorca, ale również autor wysiłku na rzecz drugiego (np. ten, który przekazał rzecz albo pewną informację komuś, czy ten, który zaprosił kogoś w odwiedziny). Przypuszczają, że podziękowanie w jednym przypadku jest formą zakończenia kontaktu, w drugim - sprawieniem przyjemności współrozmówcy, w trzecim zaś - demonstracją skromności, która ma polegać na pomniejszeniu własnych zasług. Jeden z przypadków użycia wyrazu podziękować pozostaje jednak dla Bułgara zupełnie niezrozumiały i nieprzekładalny - przypadek, w którym prymarne znaczenie wyrazu podziękować oraz funkcja jako akt mowy została diametralnie zmieniona (z ekspresywnej na deklaratywną), na przykład podziękowali $m u$ w znaczeniu 'zwolnili go z pracy'.

Za inny dowód uprzejmości polskiej mowy powszedniej Bułgarzy uważają sposób wyrażania aktów dyrektywnych - jak wiadomo, mają one na celu nacisk na odbiorcę i wpłynięcie na jego zachowanie (zob. Searle 1969). W porównaniu z bułgarskim dyskursem podobne akty mowy w Polsce reprezentowane są przez wyrazy wyrażające prośbę bądź pytanie zamiast rozkaz, czyli komunikat ukierunkowany jest na odbiorcę, od którego woli zależy przebieg działania, nie zaś na

${ }^{2}$ Na przykład leksem typu gad (bułg. zad), który we współczesnym języku bułgarskim używany jest przeważnie jako negatywne określenie człowieka. 
nadawcę, na przykład: (fotograf) Ja zaproszę Pana za 5 minut. (nie: Ja zawołam (wezwe) Pana za 5 minut.); (w przychodni) Nie trzeba wchodzić, oni proszą. (nie: Nie trzeba wchodzić, oni wzywaja (wołaja); (podczas meczu) Sędzia zaprasza na przerwę. (nie: Sędzia ogłasza (odgwizduje) przerwę.

\section{Struktura dialogu w interakcji społecznej}

Zdecydowanie z pozytywnym odbiorem spotykają się pewne cechy dialogu między Polakami w procesie interakcji społecznej. Dialog ten powoduje wrażenie pełności, obecna jest bowiem zazwyczaj zarówno część inicjalna, rozpoznawcza, na przykład autoprezentacja rozmówcy przy rozpoczęciu dialogu, jak i część finalna, zamykająca kontakt, na przykład podziękowanie za rozmowę, potwierdzenie odbioru bądź przekazanie pozdrowienia i życzenia. Na tym tle epizod werbalny między Bułgarami wygląda nieco inaczej, często bowiem cechuje go brak wspomnianych komponentów dialogu. Jako odmienna społecznie utrwalona norma zachowań językowych w Polsce odbierana jest zasada wysłuchiwania się nawzajem, nieprzerywania rozmówcy oraz nieprzerywania rozmowy przez osoby postronne.

\section{Wyrażanie relacji społecznych}

Dla Bułgarów, którzy dopiero zanurzają się w ocean polskiej codziennej komunikacji werbalnej, zarówno w sferach oficjalnych, jak i w nieoficjalnych, najbardziej wyraziste różnice w porównaniu z rodzimym dyskursem ujawniają się w zakresie językowego odzwierciedlenia relacji społecznych, na przykład tych prezentowanych pojęciami władzy (ang. power) i solidarności (ang. solidarity). Ogólnie, Bułgarzy uważają, że sieć relacji w obrębie polskiego społeczeństwa zawiera o wiele więcej niuansów niż w społeczeństwie bułgarskim, w związku z tym ich językowe wyrażenie jest bardziej skomplikowane. Jeden z przykładów dotyczy tzw. dystansu społecznego. W stosunku do tego zjawiska obserwacja wielu sytuacji komunikatywnych pozwala Bułgarom na sformułowanie następujących wniosków:

- W polskim dyskursie obecna jest tendencja do utrzymywania dystansu między komunikantami przez dłuższy okres, natomiast w dyskursie bułgarskim wiążące jest dążenie do szybkiego zneutralizowania dystansu. Odzwierciedleniem tej zasady na poziomie języka są odpowiednie formuły zwrotu (np. mówienie na pan, pani, państwo vs. mówienie po imieniu), wyrazy witania się (np. dzień dobry vs. cześć), rozstania się (np. do widzenia vs. cześć). Poza tym Bułgarzy są pod mocnym wrażeniem faktu, że dystans społeczny (głównie między różnymi generacjami) utrzymuje się nawet $\mathrm{w}$ ramach rodziny.

- Dystans społeczny w polskim społeczeństwie ma swoisty charakter kontynuacyjny, natomiast $\mathrm{w}$ ramach bułgarskiego społeczeństwa wszystkie rodzaje 
dystansu tworzą układ dychotomiczny. Bułgarzy uważają, że Polacy rozróżniają więcej rodzajów dystansu społecznego między komunikującymi się osobami niż Bułgarzy, przy tym różnym dystansom odpowiadają ściśle określone wyznaczniki językowe. Skracanie dystansu w procesie komunikacji przebiega sukcesywnie i stopniowo, a na poszczególnych etapach stosunków interpersonalnych wyznaczniki językowe jednego typu dystansu wymieniają się na wyznaczniki innego typu relacji (np.: proszę pana - panie sąsiedzie - panie + nazwisko - panie + imię sasiedzie - imię). Dla Bułgara to wieloetapowe przejście wygląda niezrozumiałe, powoduje u niego nie tylko negatywne emocje, ale również nierzadko poważne negatywne konsekwencje.

\section{Wyrażanie roli i statusu społecznego}

Podstawowa różnica między polskim a bułgarskim dyskursem w tym zakresie polega na tym, że polscy rozmówcy zmierzają zazwyczaj do dokładnego zlokalizowania partnera komunikacji (czy obiektu komunikatu w ogóle) w przestrzeni społecznej. W dyskursie werbalnym temu celowi służą wyrazy określające cechy społeczne osoby, najczęściej jej wykształcenie, wykonywany zawód, status społeczny, funkcje społeczne, miejsce w hierarchii służbowej (np. naukowej) itp. Można stwierdzić, że w opinii Bułgara mowę Polaków charakteryzuje raczej socjalizacja obiektu mowy, Bułgarzy natomiast preferują socjalną neutralizację i egalitaryzm. Uwidocznione jest to w zakresie zwrotów do partnera komunikacji, przykładowo w języku polskim: pan (pani) + nazwa statusu/roli społecznej (np.: panie mecenasie, panie doktorze, panie profesorze, panie pośle, panie trenerze, panie kierowco, panie władzo). $\mathrm{W}$ dyskursie bułgarskim adresatywa takie sprowadzają się do połączeń formy tytularnej z nazwiskiem, na przykład: adwokat Petrov, doktor Ivanov, profesor Dymitrov. W wielu wypadkach językowy wyznacznik społecznej identyfikacji wypada (np. w przypadku posła i trenera). Natomiast podobne do polskich są te formuły adresatywne, które dotyczą osób o znacznym statusie społecznym (np. minister, premier, prezydent). Dążenie Polaków do społecznej identyfikacji partnera komunikacji Bułgarom wydaje się czasem dziwne, na przykład w przypadku niższej pozycji zawodowej typu panie kierowco itp.

W nawiązaniu do powyższego dziwi również Bułgarów zasada „aktualnej przeszłości”, czyli wyróżniania określonej osoby tytułem, który jest już nieaktualny, jak choćby w przypadku nie tylko byłych prezydentów, ale również premierów, ministrów, rektorów, dziekanów i in. Duże wrażenie na Bułgarach wywiera także zasada „podwyższania stopnia zawodowego", czyli zwracanie się do obiektu mowy (lub mówienie o nim) w sposób, który wynosi go w hierarchii na pozycję wyższą niż mu jest właściwa, np. mówienie do wiceministra (czy prorektora, prodziekana, wicedyrektora) bądź o nim panie ministrze (rektorze, dziekanie, dyrektorze). W podobnych sytuacjach bułgarskie normy mowy nakazują bardziej 
precyzyjne określenie denotatu, np. gospodin zamestnik-ministyr (panie wiceministrze), gospodin zamestnik-direktor (panie zastępco dyrektora) itd.

\section{Asymetrie w zakresie językowego obrazu świata}

Poczucie różnic u nosiciela języka bułgarskiego powodują również niektóre zjawiska z zakresu tzw. językowego obrazu świata (JOŚ), rozumianego jako „zawarta $\mathrm{w}$ języku, różnie zwerbalizowana interpretacja rzeczywistości, która daje się ująć w postaci zespołu sądów o świecie" (Bartmiński 2006: 12). Jak wiadomo, w badaniach nad JOŚ podstawowym źródłem materiału służącego do rekonstrukcji owej interpretacji rzeczywistości jest mowa potoczna członków społeczeństwa - wynika to z faktu, iż potoczność „tkwi w głębokich warstwach języka, w sposobie recepcji rzeczywistości” (Bartmiński 2001: 119). Specjalnie wyróżniano tutaj rolę metaforyczności jako „niesłychanie istotnego składnika naszego codziennego języka" (Bartmiński 2001: 125). Trzeba podkreślić, że zestawienie bułgarskich metaforycznych wyrazów potocznych z ich funkcjonalnymi odpowiednikami w języku polskim ujawnia szereg podobieństw wynikających ze wspólnej europejskiej i słowiańskiej bazy kulturowej ${ }^{3}$. Jednocześnie nie można pominąć znaczących różnic w tym zakresie, związanych z odmiennymi warunkami kształtowania się obu społeczeństw, z odmienną mentalnością jego członków, z odmiennym sposobem percepcji i porządkowania świata.

Poznający codzienną polską mowę Bułgar ze zdziwieniem spostrzega wiele istotnych asymetrii przede wszystkim w dziedzinie metaforyzacji językowej. Te asymetrie często powodują nieprawidłowe używanie języka polskiego w sytuacjach, w których Bułgar dosłownie tłumaczy wyraz z rodzimego języka.

Jeden z aspektów asymetrii dotyczy „zdolności metaforyzującej” pewnych wyrazów. Bułgarom zdaje się, że niektóre polskie wyrazy mają o wiele więcej znaczeń przenośnych niż ich odpowiedniki bułgarskie. Na przykład, według Bułgarów w mowie polskiej o wiele częściej rozbrzmiewają takie wyrazy, jak: lecieć, kręcić, kupować i in. Zdaje się, że w polskiej powszechnej komunikacji werbalnej czasowniki te stosowane są znacznie częściej niż w mowie bułgarskiej. Można pokazać to na przykładzie czasownika lecieć.

Bazując na klasycznej definicji metafory jako powiązania dwóch różnych domen pojęciowych, czyli „X rozumiane jako Y” (Lakoff, Johnson 1988: 132), można wyciągnąć wniosek, iż nosiciele języka i kultury polskiej więcej zjawisk z otaczającej rzeczywistości odnoszą do aktu latania, czyli rozumieją, widzą jako latanie, niż nosiciele języka i kultury bułgarskiej, na przykład: Samolot leci. Jabtka leca z drzewa. Dachówki leca. Woda (gaz, krew) leci. Zimno leci przez okno. Dym leci z komina. Dokad ta droga leci? Ciśnienie leci. Ceny (kursy walut) leca. Czas leci. Lecę do domu. Film (muzyka) leci. Muszę odpoczać, bo lecę po robocie. Leci na młode dziewczyny. W kulki ze mna leci $\mathrm{i}$ in. W większości przytoczonych

3 Tzw. common culcural grown (zob. van Dijk 2003: 9). 
przykładów funkcjonalnym odpowiednikiem w języku bułgarskim nie jest czasownik leciećt.

Elementy eksponujące asymetryczność polsko-bułgarską przy metaforyzacji można odnaleźć w ramach rozmaitych pól semantycznych. Jedną z najliczniejszych grup tworzą wyrazy określające człowieka na podstawie wyglądu, cech charakteru, stanu psychicznego lub społecznego bądź jego zachowań. Wyrazy te odzwierciedlają specyficzne realia lub specyficzny sposób percepcji i wartościowania rzeczywistości, por.:

'bardzo chudy, suchy człowiek'- bułg. чироз [cziroz] (dosł. suszona skumbria), pol. szczapa (bułg. треска [treska]);

'naiwny, prosty, człowiek, którego łatwo można oszukać' - bułg. шаран [szaran] (dosł. karp), pol. jeleń, frajer «niem. freier〉;

'gruba, niezdarna, niezadbana kobieta'- bułg. дропла [dropła] (dosł. drop łac. otis tarda - ptak bardzo duży, podobny do żurawia), pol. gelejza, guła, klofta (regionalizmy poznańskie);

'denerwujący, irytujący człowiek' - bułg. ųирей [cyrej] (dosł. czyrak, wrzód), pol. dokuczliwy, wkurzajacy, upierdliwy;

'niepoważny, rozpieszczony' - bułg. лигльо [liglo] < лига> (dosł. ślina, czyli 'komu cieknie ślina z ust'), r.ż. лигла, pol. księżniczka, królewna;

'niezaradny, niezdarny, mało energiczny' - bułg. поплювко [popluwko] < czas. плюя> dosł. pluć, czyli 'który ślini się podczas mówienia', pol. ciapa (od nazwy mąki do wypieków u Arabów, Pakistańczyków, Hindusów, przenośnie - pogardliwie w odniesieniu do nich), oferma;

'osoba bardzo bogata' - bułg. въшкав [wyszkaw] (dosł. wszawy, zawszony), pol. nadziany;

'patrzeć bez zrozumienia' - bułg. зверя се [zwerja se] < звяр> zwierzę, czyli 'patrzeć jak zwierzę', pol. gapić się (niem. gapen, gaften);

'głęboko przeżywać' - bułg. впрягам се [wprjagam se] (dosł. zaprzęgać się), pol. przejmować się;

'uczyć się na pamięć' - bułg. кълва [kyłwa] (dosł. dziobać) - pol. kuć, zakuwać (bułg. кова, оковавам);

'starać się przechytrzyć' - bułg. дяволувам [djawołuwam] (dosł. zachować się jak diabet), pol. kręcić, wykręcać się.

Asymetrie w zakresie metaforyzacji rzeczywistości można znaleźć także w obrębie innych grup tematycznych, na przykład: pol. otwarcie/zamknięcie konferencji - bułg. откриване/закриване на конференция (dosł. odkrywanie/pokrywanie konferencji); pol. chodzi mi po głowie - bułg. върти ми се в главата (dosł. kręci mi się w głowie); pol. nie wychodzi mi - bułg. не ми се получава (dosł. nie otrzymuje się, nie okazuje się); pol. ciasno jest (np. w czołówce tabeli) - bułg. zъcmo

${ }^{4}$ Zob. Załacznik na końcu artykułu zawierający szczegółowe informacje na temat znaczeń czasownika lecieć w języku polskim i ich funkcjonalnych odpowiedników w języku bułgarskim (na podstawie: Dunaj red. 2007, Czeszewski 2006). 
e (dosł. gęsto jest); pol. złapać gumę (kapcia) - bułg. спукам гума (dosł. pękła mi guтa); pol. zbieram się - bułg. стягам ce (dosł. ściagam się, ściskam się); pol. stońce świeci (grzeje) - bułg. сльнце грее (ale: свети ми в очите - razi mnie w oczy); pol. przebrać się za kogoś - bułg. престоря за някого (dosł. иdawać kogoś); pol. klucze sa na wierzchu (pod ręką) - bułg. ключовете са ми под ръка; pol. podlegać (komuś) - bułg. подчинен съм (dosł. mieć niższy stopień); pol. zakończenie - bułg. заключение; pol. po deszczu, po fakcie, być po obiedzie - bułg. спря да вали, при свършен факт, обядвал съм; pol. sieć szybkiej obstugi-bułg. верига за бързо хранене (dosł. lańcuch szybkiego jedzenia) i in.

Uważam, że asymetrie polsko-bułgarskie w zakresie metaforyzacji są tak liczne i często tak znaczące, że zasługują na odrębne pogłębione badania.

Język polski i język bułgarski, które mają wspólne korzenie słowiańskie, wspólną leksykę i wiele zbieżnych cech systemowych, pod względem społecznego zastosowania wykazują znaczące rozbieżności. Dotyczą one kształtu produkcji językowej pod względem aktów mowy, językowego wyrażania relacji, roli i statusu społecznego, sposobu językowej interpretacji rzeczywistości i in. Nie ma wątpliwości, iż ujawnienie norm zachowań językowych członków danego społeczeństwa ma istotne znaczenie - zarówno teoretyczne, jak i praktyczne - a jedną z możliwych metod skutecznych badań stanowić może, jak spróbowaliśmy pokazać, metoda obserwatora zewnętrznego.

\section{Aneks}

\section{Polski czasownik lecieć i jego bułgarskie odpowiedniki funkcjonalne}

(podkreślone wyrazy stanowią pełne odpowiedniki)

Lecieć (Dunaj red. 2007: 744)

1. 'przemieszczać się w powietrzu w wybranym kierunku; odbywać podróż drogą powietrzną'

W górze leci samolot. Lecieć balonem. Leca klucze żurawi.

Bułg. Горе лети самолет. Детя с балон. Детят ята жерави.

2. 'spadać w dół, staczać się, upadać, opadać, ulegać sile grawitacji'

Leca jabłka z drzewa. Leca dachówki z dachu.

Bułg. Падат (сипят се) ябълки от дървото. Падат (хвърчат, летят) керемиди от покрива.

3. 'wydobywać się skądś, lać się, wylewać, rozsypywać, rozprzestrzeniać, ulatniać się'

Woda leci z kranu. U Kowalskich leci gaz. Wojtkowi leci krew z nosa. Iskry leca z komina.

Bułg. Вода тече (иурти) от чешмата. У Ковалски изтича газ. На Войтек му тече (иурти) кръв от носа. Искри излитат от комина. 
4. pot. 'gwałtownie obniżać się, spadać, zmniejszać się, tracić na wartości, intensywności'

Ciśnienie leci. Kursy akcji leca. Leca ceny zboża.

Bułg. Налягането пада. Курсовете на акииите се сриват (падат). Сриват се иените на житото.

5. 'bardzo szybko mijać, przebiegać, upływać, zachodzić w czasie'

Leca dni, miesiace. Lata lecą.

Bułg. Детят (минават) дни и месеии. Петят (минават) годините.

6. pot. 'biec bardzo szybko, pędzić, gnać, spieszyć się'

Lecieć co tchu. Lecieć na wyktad. Lecieć po butki.

Bułg. Бягам (бързам, духвам) на лекиия. Бягам (духвам, отивам) за хляб.

7. pot. 'być nadawanym w radiu, telewizji, itp.'

Właśnie leci mój ulubiony film. Jaki ma tytut ta piosenka, która teraz leci.

Bułg. Точно върви (дават) моя любим филм. Как се казва тази песен, която сега върви (пускат).

8. pot. (na kogoś) 'interesować się kimś, mieć ochotę na kontakty seksualne z kimś'

Lecieć na młode dziewczyny.

Bułg. налитам (падам си по) на млади момичета.

Lecieć (Czeszewski 2006: 152)

1. 'słaniać się ze zmęczenia':

Zrób mi tu jakiejś kawy, bo lecę po robocie.

Bułg. Направи ми някакво кафе, че падам от работа.

2. 'iść, wychodzić, wracać':

Lece już, naprawdę muszę. Trzymaj się zdrowo!

Bułg. Тръгвам (бягам) вече, наистина трябва. Всичко хубаво.

3. 'odczuwać do kogoś pociąg seksualny, interesować się kimś; odczuwać do czegoś wyjątkowy pociąg, chcieć coś zdobyć, osiągnąć':

Chris leci na wszystko, co ma cycki. (SC) Wiem, że na siebie lecicie, to się czuje.

Bułg. Крис налита на всичко, което има ичицки. Знам, че си падате взаимно, това се чувства.

4. 'egzystować dzięki czemuś; także zażywać narkotyki':

... spotkałam dawna znajomą. Leci na rolkach. Tak otępiałego ćpuna to jeszcze nigdy nie widziałam.

... срещнах някогашна позната. Друса се, та се къса. Такава тъпа наркоманка не бях виждала.

5. 'lekceważyć kogoś, robić sobie z kogoś żarty; pozwalać sobie na zbyt wiele': W kulki sobie ze mna grasz (lecisz)?! Możesz zarobić kulkę w teb!

Bułg. Майтап си правиш (майтапиш се, бъзикаш се, гъбаркаш се) с мене. 


\section{Bibliografia}

Bartmiński J., 2001, Styl potoczny, w: Współczesny język polski, red. J. Bartmiński, Lublin, s. 115-134.

Bartmiński J., 2006, Językowe podstawy obrazu świata, Lublin.

Bartmiński J., 2009, Stereotypy mieszkają w języku, Lublin.

Czeszewski M., 2006, Stownik polszczyzny potocznej, Warszawa.

Dunaj B., (red.), 2007, Współczesny słownik języka polskiego, Warszawa.

Grabias S., 1997, Język w zachowaniach społecznych, Lublin.

Хъдсън Р., 1995, Социолингвистика, София.

Lakoff G., Johnson M., 1988, Metafory w naszym życiu, przeł. T.P. Krzeszowski, Warszawa.

Searle J., 1969, Speech Acts: An essay in the philosophy of language, Cambridge University Press.

Сотиров П., 2006, От съпоставителни граматики към съпоставителен анализ на дискурси, w: Славистика и общество, ред. М. Младенова, И. Монова, София, c. $73-76$.

Sotirov P., 2007, Zachowania językowe Polaków w wyobrażeniach Bułgarów zamieszkatych $w$ Polsce, w: Potoczność a zachowania językowe Polaków, red. B. Boniecka, S. Grabias, Lublin, s. 193-203.

Степанов Ю., 1979, Семиотика, София.

van Dijk T. A., 2003, Dyskurs polityczny i ideologia, „Etnolingwistyka” 15, s. 7-28. 